\title{
Construct validity and reliability of the Brazilian version of Hypertension Knowledge-Level Scale
}

\author{
Validação do construto e confiabilidade da versão brasileira \\ da Hypertension Knowledge-Level Scale
}

Validación de construto y confiabilidad de la versión brasileña de Hypertension Knowledge-Level Scale

\author{
Mireille Janczyk Hereibi ${ }^{\mathrm{a}}$ \\ Juliana Perez Arthur ${ }^{b}$ \\ Maria de Fátima Mantovani ${ }^{b}$ \\ Ângela Taís Matteic \\ Wendy Julia Mariano Viante ${ }^{\mathrm{d}}$ \\ Carina Bortolato-Major
}

\section{How to cite this article:} Hereibi MJ, Arthur JP, Mantovani MF, Mattei AT, Bortolato-Major C. Construct validity and reliability of the Brazilian version of Hypertension Knowledge-Level Scale. Rev Gaúcha Enferm. 2021;42:e20190429. doi: https://doi.org/10.1590/19831447.2021.20190429

\footnotetext{
a Prefeitura Municipal de São José dos Pinhais, Secretaria Municipal de Saúde, Departamento de Atenção à Saúde. São José dos Pinhais, Paraná, Brasil.

- Universidade Federal do Paraná (UFPR) Departamento de Enfermagem. Curitiba, Paraná Brasil.

'Conselho Regional de Enfermagem, Subseção Londrina. Londrina, Paraná, Brasil.

¿ Universidade Federal do Paraná (UFPR), Complexo Hospital de Clínicas. Curitiba, Paraná, Brasi.

Universidade Estadual do Norte do Paraná (UENP), Campus Luiz Meneghel. Bandeirantes, Paraná, Brasil.
}

\section{ABSTRACT}

Objective: To validate the construct and test the reliability of the Brazilian version of Hypertension Knowledge-Level Scale. Methods: Methodological research with 220 participants in a primary health care unit from Curitiba, Paraná. The data were collected with a social demographic questionnaire and the Brazilian version of the scale. The construct validity and reliability were assessed using Cronbach's Alpha, Pearson's Correlation and Analysis of Variance. The discriminant validity was verified comparing groups of people with hypertension and without, using $T$ test.

Results: Cronbach's Alpha was 0.74 . The groups comparison showed that people with hypertension had better results $(p<0,001)$. Pearson's Correlation showed that the questions measure different aspects of the same construct, justifying its organization in subdimensions. Conclusion: The Brazilian version of Hypertension Knowledge-Level Scale is a reliable instrument, which had its construct and criterion validated to measure knowledge about hypertension among Brazilian people. It can help health professionals with planning educative actions

Keywords: Validation study. Surveys and questionnaires. Hypertension. Knowledge.

\section{RESUMO}

Objetivo: Validar o construto e testar a confiabilidade da versão brasileira da Hypertension Knowledge-Level Scale.

Método: Pesquisa metodológica realizada com 220 participantes em uma unidade de saúde de Curitiba, Paraná. Os dados foram coletados mediante um questionário sociodemográfico e a versão brasileira da escala. A validade de construto e confiabilidade foram avaliadas pelos testes Alpha de Cronbach, correlação de Pearson e análise da variância. Verificou-se a validade discriminante, comparando grupos de hipertensos e não hipertensos por meio do Teste T.

Resultados: 0 Alpha de Cronbach foi 0,74. Ao comparar os grupos, constatou-se que pessoas com hipertensão tiveram melhor desempenho $(p<0,001)$. A correlação de Pearson indicou que as variáveis medem faces diferentes do mesmo construto, justificando a organização em subdimensões.

Conclusão: A versão brasileira da Hypertension Knowledge-Level Scale é um instrumento confiável, que teve seu construto e critério validados para medir conhecimento sobre a hipertensão em brasileiros. Sua utilização pode auxiliar profissionais de saúde no planejamento de ações educativas

Palavras-chave: Estudo de validação. Inquéritos e questionários. Hipertensão. Conhecimento.

\section{RESUMEN}

Objectivo: Validar el constructo y testar la confiabilidad de la versión brasileña de Hypertension Knowledge-Level Scale. Método: Investigación metodológica realizada con 220 participantes de una unidad de salud de atención primaria de Curitiba, Paraná. Los datos se colectaron por medio de un cuestionario sociodemográfico y la versión brasileña de la escala. La validad del constructo y la confiabilidad se avaliaron por medio de los testes Alpha de Cronbach, correlación de Pearson y analisis de la variancia. La validad discriminante se comprobó comparando grupos de hipertensos y no hipertensos por medio del Teste T.

Resultados: El Alpha de Cronbach fue 0,74. La comparación de grupos comprobó que personas com hypertensión se desempeñaron mejor ( $p<0,001)$. La correlación de Pearson indicó que las variables miden diferentes aspectos del mismo constructo, justificando la organización en subdimensiones.

Conclusión: La versión brasileña de Hypertension Knowledge-Level Scale es un instrumento confiable, con constructo e criterio validados para medir concimiento acerca de la hypertensión em brasileños. La escala puede ayudar profesionales de salud a planear acciones educativas.

Palabras clave: Estudio de validación. Encuestas y cuestionarios. Hipertensión. Conocimiento. 


\section{INTRODUCTION}

The individual's understanding of their own health condition influences the adherence to information and guidance provided by health professionals and in cooperation with the therapeutic regimen ${ }^{(1)}$. In this context, health education is crucial for the prevention of health problems, since, gaining health literacy, the user is instrumental in making informed choices regarding their treatment and understanding the implications of their decisions(2).

One of the challenges in relation to health education refers to chronic non-communicable diseases, which are considered a public health problem because, in addition to impacting the functionality and quality of life of the population, they are responsible for high mortality rates in Brazil and in the world. Among chronic diseases, cardiovascular diseases predominate, with Systemic Arterial Hypertension (SAH) being the most frequent, mainly among the elderly ${ }^{(3)}$.

Achieving lifestyle changes and promoting better blood pressure control requires the promotion of knowledge about the disease, its complications and the care actions necessary for the treatment of $\mathrm{SAH}^{(2)}$.

In order to assess people's knowledge of SAH and to direct health education strategies, researchers from the Public Health department of a Faculty of Medicine in Turkey developed and validated the Hypertension Knowledge-Level Scale (HK-LS), a scale composed of 22 statements. The researchers evaluated the internal consistency using Cronbach's Alpha and obtained a coefficient of 0.82 . Discriminant validity was tested by comparing groups of hypertensive and non-hypertensive individuals with the TTest ${ }^{(4)}$.

In 2016, HK-LS was translated and cross-culturally adapted to Brazilian Portuguese, underwent a pre-test with 40 participants and validated the content, obtaining a Content Validity Index of $0.96^{(5)}$.

In view of the above, the Brazilian version of the scale had its content validated, but it was not evaluated as to the other psychometric properties as a construct and reliability in the Brazilian population, a fact that led to the development of this research, which has the following guiding question "Is the Brazilian version of the Hypertension Knowledge-Level Scale reliable and does it measure the knowledge of people with hypertension about the disease?". Therefore, the objective of this research is to validate the construct and test the reliability of the Brazilian version of the Hypertension Knowledge-Level Scale.

\section{$\square$ METHOD}

This is a methodological research with a quantitative component, developed in a health unit in Curitiba, Paraná, chosen for convenience.

For the definition of the sample number, it was followed the recommendation for validation studies, which suggests a proportion of 10 respondents for each item of the instrument to be evaluated ${ }^{(6)}$. Bearing in mind that the scale has 22 items, 220 participants were included, who complied the following eligibility criteria: being an adult over 18 years old and having a definitive registration at the referred health unit. The exclusion criterion was the failure to fill in any HK-LS question.

Data collection was carried out from December 2017 to February 2018, after participants signed the informed consent form, by completing a sociodemographic questionnaire with clinical variables and the translated and adapted version of the HK-LS ${ }^{(5)}$.

HK-LS has 22 statements, divided into six subdimensions: "definition" (questions 1 and 2), "medical treatment" (questions 6,7, 8 and 9), "medication adherence" (questions 3,4, 5 and 12), "lifestyle" (questions 10,11,13, 16 and 17), "diet" (questions 14 and 15) and "complications" (questions 18,19,20, 21 and 22). The answer options are: "right", "wrong" and "I don't know". For the sum of the scores, each correctly marked alternative adds up a point and the option "I don't know" is considered an incorrect answer. Thus, the final score can vary from 0 to $22^{(4-5)}$.

The data were tabulated in Microsoft Exce ${ }^{\circledast}$ spreadsheets by two previously trained people, independently, and were later validated by the "exact" tool. The sociodemographic variables were analyzed descriptively.

To check the construct validity and test the reliability of the Brazilian version of the HK-LS, it was used Pearson's $R$ linear correlation matrix analysis, $F$ test of variance analysis, Cronbach's alpha and $T$ test for group comparison.

Pearson's $\mathrm{R}$ linear correlation coefficient $\mathrm{R}$ allows the construction of a correlation matrix and assesses the strength and direction of the relationship between pairs of items, and was used to identify the interdependence between the 22 HK-LS variables ${ }^{(6)}$.

The Analysis of Variance (ANOVA) presents the sum of squares for the variance between the data and variables and, with this, obtains the F test, which indicates the source of variation among the participants. From this analysis, it is possible to analyze whether all items were useful or if any statement could be discarded ${ }^{(6)}$. 
Cronbach's Alpha measures the instrument's internal consistency and reliability. For Cronbach's Alpha, a value of 0.60 was considered acceptable and satisfactory when greater than $0.70^{(6)}$.

Finally, the discriminant validation was performed with hypothesis testing by comparing the correct answers by HK-LS subdimension between those with and without SAH; thus configuring the construct validity ${ }^{(7)}$. To confirm the discriminant validity, it is accepted the hypothesis that the level of knowledge is higher among people with personal or family history of SAH, as confirmed in the development research of HK-LS(4).

The research is part of a project entitled "Translation and cross-cultural adaptation of a questionnaire on systemic arterial hypertension", which was approved by the Research Ethics Committees of a public University in the south of the country (statement 2.030.203) and the Municipal Health Office (protocol 104/2016), and meets the ethical aspects contained in Resolution 466/2012 of the National Health Council/National Commission for Ethics in Research.

\section{RESULTS}

From 220 people in the sample, 161 (73.18\%) were female, 65 (29.55\%) were over 60 years old, 103 (46.82\%) had a diagnosis of SAH and $124(56,36 \%)$ had less than nine years of schooling.

When testing the discriminant validity, it was found that the group of people with SAH obtained better results in the subdimensions "definition", "medical treatment", "lifestyle", "diet" and "complications". However, people without a diagnosis of SAH were more successful in the "medication adherence" subdimension. The differences in scores were significant $(p<0.06)$ for all subdimensions, except for "medical treatment" $(p=0.329)$ (Table 1).

Regarding the reliability of the Brazilian version of HK-LS, the overall coefficient was 0.74 . It was verified whether the removal of any statement would increase the value of Cronbach's Alpha and this did not happen, demonstrating that the variables are correlated and evaluate the same construct, not being expendable for the analysis of knowledge (Table 2).

Table 1 - Average of correct answers of the participants $(n=220)$ in each HK-LS subdimension. Curitiba, PR, Brazil, 2018

\begin{tabular}{|c|c|c|c|}
\hline $\begin{array}{c}\text { HK-LS } \\
\text { Subdimensions }\end{array}$ & $\begin{array}{l}\text { Without arterial hypertension } \\
\qquad \begin{array}{c}(\mathrm{n}=103) \\
(\mathrm{Avg} \pm \mathrm{SD})\end{array}\end{array}$ & $\begin{array}{l}\text { With rterial hypertension } \\
\qquad \begin{array}{l}(\mathbf{n}=117) \\
\text { (Avg } \pm \text { SD) }\end{array}\end{array}$ & p-value* \\
\hline Definition & $1.29 \pm 0.73$ & $1.58 \pm 0.66$ & 0.001 \\
\hline Medical treatment & $3.32 \pm 0.92$ & $3.37 \pm 0.73$ & 0.329 \\
\hline Medication adherence & $3.33 \pm 0.96$ & $2.65 \pm 1.24$ & $<0.001$ \\
\hline Lifestyle & $4.64 \pm 0.75$ & $4.82 \pm 0.52$ & 0.021 \\
\hline Diet & $1.32 \pm 0.87$ & $1.58 \pm 0.65$ & 0.009 \\
\hline Complications & $3.97 \pm 1.12$ & $4.82 \pm 0.48$ & $<0.001$ \\
\hline
\end{tabular}

Source: Research data, 2018.

Caption: HK-LS: Hypertension Knowledge-Level Scale. Avg: Average. DP: Standard deviation

Note: * Unilateral T test

Table 2 - Simulation of the coefficient resulting from Cronbach's Alpha with the removal of each statement from HK-LS. Curitiba, PR, Brazil, 2018

\begin{tabular}{|c|c|c|c|}
\hline Scale items & Average & Variance & $\begin{array}{c}\text { Resulting } \\
\text { Cronbach's } \\
\text { Alpha }\end{array}$ \\
\hline $\begin{array}{l}\text { 1) High systolic (maximum) or diastolic (minimum) blood pressure } \\
\text { indicates an increase in blood pressure. }\end{array}$ & 31.88 & 18.30 & 0.74 \\
\hline $\begin{array}{l}\text { 2) Elevated (minimum) diastolic blood pressure also indicates an } \\
\text { increase in blood pressure. }\end{array}$ & 31.67 & 17.64 & 0.73 \\
\hline
\end{tabular}


Table 2 - Cont.

\begin{tabular}{|c|c|c|c|}
\hline Scale items & Average & Variance & $\begin{array}{c}\text { Resulting } \\
\text { Cronbach's } \\
\text { Alpha }\end{array}$ \\
\hline $\begin{array}{l}\text { 3) High blood pressure is caused by aging, so it does not } \\
\text { need treatment. }\end{array}$ & 31.29 & 18.89 & 0.73 \\
\hline $\begin{array}{l}\text { 4) If the medication for high blood pressure can control blood pressure, } \\
\text { there is no need for a change in lifestyle. }\end{array}$ & 31.48 & 18.52 & 0.73 \\
\hline $\begin{array}{l}\text { 5) If people with high blood pressure change their lifestyles, there is no } \\
\text { need for treatment. }\end{array}$ & 31.48 & 18.56 & 0.73 \\
\hline $\begin{array}{l}\text { 6) People with high blood pressure should take their medication in the } \\
\text { way they consider most appropriate. }\end{array}$ & 31.50 & 19.10 & 0.73 \\
\hline 7) Medication for high blood pressure should be taken daily. & 32.18 & 19.33 & 0.73 \\
\hline $\begin{array}{l}\text { 8) People with high blood pressure should take their medication only } \\
\text { when they feel bad. }\end{array}$ & 31.30 & 19.21 & 0.73 \\
\hline $\begin{array}{l}\text { 9) People with high blood pressure should take their medication for the } \\
\text { rest of their lives. }\end{array}$ & 31.91 & 17.66 & 0.72 \\
\hline $\begin{array}{l}\text { 10) For people with high blood pressure, frying is the best way to } \\
\text { prepare food. }\end{array}$ & 31.27 & 19.48 & 0.73 \\
\hline $\begin{array}{l}\text { 11) For people with high blood pressure, cooking only in water or } \\
\text { grilling are the best ways to prepare food. }\end{array}$ & 32.13 & 18.45 & 0.72 \\
\hline $\begin{array}{l}\text { 12) People with high blood pressure can eat food without controlling } \\
\text { the amount of salt as long as they take their medication every day. }\end{array}$ & 31.34 & 19.51 & 0.73 \\
\hline $\begin{array}{l}\text { 13) People with high blood pressure should eat fruits and } \\
\text { vegetables frequently. }\end{array}$ & 32.18 & 18.95 & 0.72 \\
\hline $\begin{array}{l}\text { 14) he best type of meat for people with high blood pressure is } \\
\text { red meat. }\end{array}$ & 31.17 & 17.63 & 0.71 \\
\hline $\begin{array}{l}\text { 15) The best type of meat for people with high blood pressure is } \\
\text { white meat. }\end{array}$ & 31.87 & 16.79 & 0.71 \\
\hline 16) People with high blood pressure should not smoke. & 32.19 & 19.35 & 0.73 \\
\hline 17) People with high blood pressure can drink alcohol at will. & 31.28 & 20.00 & 0.74 \\
\hline $\begin{array}{l}\text { 18) If high blood pressure is not treated it can cause stroke/ } \\
\text { cerebrovascular accident (CVA). }\end{array}$ & 32.19 & 19.55 & 0.73 \\
\hline $\begin{array}{l}\text { 19) If high blood pressure is not treated it can cause a } \\
\text { heart attack/infarction }\end{array}$ & 32.23 & 19.71 & 0.73 \\
\hline $\begin{array}{l}\text { 20) If high blood pressure is not treated it can cause early } \\
\text { death/anticipate death. }\end{array}$ & 32.17 & 18.76 & 0.72 \\
\hline $\begin{array}{l}\text { 21) If high blood pressure is not treated it can cause the kidneys to } \\
\text { stop working. }\end{array}$ & 31.66 & 15.69 & 0.70 \\
\hline 22) If high blood pressure is not treated it can cause vision problems. & 31.89 & 17.22 & 0.72 \\
\hline
\end{tabular}

Source: Research data, 2018. 
The value of Cronbach's alpha calculated for each subdimension can be seen in table 3. The subdimension with the lowest alpha value was "medical treatment", while the highest value corresponds to the "medication adherence" subdimension.

In the analysis of variance, it was found that the source of variation among the participants was considered low in relation to the total, which suggests that the sample is cohesive. Now the variability between items is expected and considered adequate because it is not extreme (very low or very high) in relation to the total. The $\mathrm{p}$-value for the $\mathrm{F}$ test $(p<0.01)$ indicates that none of the questions on the scale can be considered disposable (Table 4).

Pearson's correlation coefficients found for each HK-LS item are shown in Table 5.

In the correlation matrix, the values ranged from -0.181 to +0.540 , with 196 correlations being positive and 35, negative. In "medical treatment" and "lifestyle" there were negative correlations between variables of the same subdimension. The closer to $+1,000$, the greater the correlation. Thus, it is possible to notice a low correlation between most of the questions.

The highest correlations were 0.540 between statements 14 and 15 (both from the "diet" subdimension), and 0.510 between statements 21 and 22 (both from the "complications" subdimension). The lowest correlations were between statements 11 and 17 (both from the "lifestyle"subdimension) with a coefficient of -0.181 , and between statements 12 ("medication adherence") and 18 ("complications" subdimension), with a coefficient of -0.056 .

The statements that obtained the highest number of negative correlations were 1 (subdimension "definition", in relation to questions 5,6,12,13, 19); 7 (subdimension"medical treatment", in relation to questions 8,10,16,18, 19), 12 (subdimension "medication adherence", in relation to questions
Table 3 - Cronbach's al pha coefficient per HK-LS subdimension. Curitiba, PR, Brazil, 2018

\begin{tabular}{lc} 
Subdimension & $\begin{array}{c}\text { Cronbach's alpha } \\
\text { coefficient }\end{array}$ \\
\hline Definition & 0.52 \\
Medical treatment & 0.29 \\
Medication adherence & 0.94 \\
Lifestyle & 0.84 \\
Diet & 0.92 \\
Complications & 0.91 \\
\hline
\end{tabular}

Source: Research data, 2018

$1,9,11,18,19,20), 16$ ( subdimension "lifestyle", in relation to questions $6,7,8,9,17,18,19,20)$, and 17 (subdimension "lifestyle", in relation to questions $2,5,11,15,16,22)$.

\section{DISCUSSION}

The results of this study demonstrated the construct validity and strong reliability of the HK-LS scale in the adult population enrolled in a health unit in Curitiba, and state that HK-LS effectively measures knowledge about the disease and is reliable, thus confirming, the authors' cross-cultural validation and adaptation ${ }^{(4-5)}$.

The prevalence of women in the sample is in line with other studies conducted with hypertensive patients in basic health units ${ }^{(8-9)}$, as well as the age group of the participants, in which patients over 60 years old predominated $(29,55 \%)^{(9-10)}$.

Table 4 - Analysis of variance for the Brazilian version of HK-LS. Curitiba, PR, Brazil, 2018

\begin{tabular}{lcccc}
\multicolumn{1}{c}{ Analysis of Variance } & Total sum of squares & Quadratic mean & F Test & p-value \\
\hline Among participants & 201.148 & 0.918 & & \\
Among the items & 653.634 & 31.125 & 127.969 & $<0.01^{*}$ \\
Residual & 1118.593 & 0.243 & \\
Total & 1973.375 & & \\
\hline
\end{tabular}

Source: Research data, 2018.

Note: * Analysis of Variance (Anova). 
Hereibi MJ, Arthur JP, Mantovani MF, Mattei AT, Bortolato-Major C

Table 5 - Pearson's correlation coefficient among the 22 items that make up the HK-LS. Curitiba, PR, Brazil, 2018

\begin{tabular}{|c|c|c|c|c|c|c|c|c|c|c|c|c|c|c|c|c|c|c|c|c|c|}
\hline 1 & 2 & 3 & 4 & 5 & 6 & 7 & 8 & 9 & 10 & 11 & 12 & 13 & 14 & 15 & 16 & 17 & 18 & 19 & 20 & 21 & 22 \\
\hline 11.000 & 0.356 & 0.054 & 0.052 & -0.060 & -0.043 & 0.067 & 0.019 & 0.079 & 0.038 & 0.057 & -0.100 & -0.032 & 0.070 & 0.176 & 0.096 & 0.007 & 0.025 & -0.056 & 0.086 & 0.164 & 0.142 \\
\hline 2 & 1.000 & 0.020 & 0.086 & 0.120 & 0.030 & 0.214 & 0.073 & 0.079 & 0.092 & 0.118 & 0.058 & 0.041 & 0.020 & 0.109 & 0.140 & -0.015 & -0.047 & -0.025 & 0.122 & 0.163 & 0.174 \\
\hline 3 & & 1.000 & 0.221 & 0.193 & 0.070 & 0.050 & 0.202 & 0.152 & 0.307 & 0.070 & 0.245 & 0.129 & 0.202 & 0.147 & 0.137 & 0.096 & 0.050 & 0.009 & 0.017 & 0.089 & 0.026 \\
\hline 4 & & & 1.000 & 0.270 & 0.254 & 0.011 & 0.224 & 0.122 & 0.056 & 0.104 & 0.190 & 0.040 & 0.088 & 0.116 & 0.078 & 0.030 & 0.144 & 0.137 & 0.002 & 0.214 & 0.120 \\
\hline 5 & & & & 1.000 & 0.279 & 0.066 & 0.190 & 0.161 & 0.053 & 0.161 & 0.083 & 0.181 & 0.173 & 0.171 & 0.026 & -0.018 & 0.224 & 0.218 & 0.092 & 0.057 & -0.031 \\
\hline 6 & & & & & 1.000 & 0.055 & 0.164 & 0.070 & 0.133 & -0.033 & 0.152 & 0.026 & 0.249 & 0.129 & -0.056 & 0.029 & 0.006 & -0.040 & 0.011 & 0.137 & 0.105 \\
\hline 7 & & & & & & 1.000 & -0.140 & 0.262 & -0.081 & 0.237 & 0.099 & 0.155 & 0.021 & 0.005 & -0.038 & 0.184 & -0.042 & -0.024 & 0.253 & 0.216 & 0.229 \\
\hline 8 & & & & & & & 1.000 & 0.120 & 0.175 & 0.168 & 0.119 & 0.105 & 0.182 & 0.110 & -0.055 & 0.051 & 0.119 & 0.085 & 0.067 & 0.162 & 0.130 \\
\hline 9 & & & & & & & & 1.000 & 0.041 & 0.141 & -0.044 & 0.165 & 0.157 & 0.185 & -0.009 & 0.113 & 0.197 & 0.253 & 0.306 & 0.318 & 0.250 \\
\hline 10 & & & & & & & & & 1.000 & 0.164 & 0.249 & 0.144 & 0.275 & 0.180 & 0.154 & 0.153 & -0.087 & -0.146 & 0.017 & 0.016 & -0.047 \\
\hline 11 & & & & & & & & & & 1.000 & -0.017 & 0.347 & 0.266 & 0.322 & 0.327 & -0.181 & 0.117 & 0.124 & 0.239 & 0.240 & 0.234 \\
\hline 12 & & & & & & & & & & & 1.000 & 0.126 & 0.125 & 0.062 & 0.126 & 0.241 & -0.166 & -0.101 & -0.012 & 0.101 & 0.058 \\
\hline 13 & & & & & & & & & & & & 1.000 & 0.230 & 0.292 & 0.116 & 0.029 & 0.085 & 0.040 & 0.251 & 0.266 & 0.039 \\
\hline 14 & & & & & & & & & & & & & 1.000 & 0.540 & 0.163 & 0.019 & -0.000 & 0.101 & 0.153 & 0.248 & 0.212 \\
\hline 15 & & & & & & & & & & & & & & 1.000 & 0.268 & -0.054 & -0.058 & 0.062 & 0.140 & 0.268 & 0.177 \\
\hline 16 & & & & & & & & & & & & & & & 1.000 & -0.119 & -0.035 & -0.020 & -0.038 & 0.131 & 0.138 \\
\hline 17 & & & & & & & & & & & & & & & & 1.000 & 0.028 & 0.016 & 0.156 & 0.014 & -0.094 \\
\hline 18 & & & & & & & & & & & & & & & & & 1.000 & 0.351 & 0.387 & 0.263 & 0.048 \\
\hline 19 & & & & & & & & & & & & & & & & & & 1.000 & 0.270 & 0.182 & 0.193 \\
\hline 20 & & & & & & & & & & & & & & & & & & & 1.000 & 0.343 & 0.220 \\
\hline 21 & & & & & & & & & & & & & & & & & & & & 1.000 & 0.510 \\
\hline 22 & & & & & & & & & & & & & & & & & & & & & 1.000 \\
\hline
\end{tabular}

Source: Research data, 2018. 
According to the VII Brazilian Hypertension Guideline ${ }^{(11)}$, ging is a risk factor for $\mathrm{SAH}$, as it favors several mechanisms that culminate in arterial stiffening, which increases blood pressure levels.

The participation of hypertensive patients (46.82\%) was lower than that of non-hypertensive patients. The patients in this study were approached regardless of their clinical condition, since it is not necessary to manifest the disease to know about it.

There was a predominance of participants with less than nine years of schooling $(56.36 \%)$, which corroborates with several studies with hypertensive patients conducted in Brazil $^{(8-9)}$. In a study carried out in primary care in Bahia, the authors found an association between low education and lack of control of blood pressure levels ${ }^{(12)}$.

Other authors have also identified that low education has a direct influence on the patient's knowledge of SAH and on how it is perceived and understood by him ${ }^{(8)}$.

The application of HK-LS demonstrated that both hypertensive and non-hypertensive individuals have important gaps in their knowledge about SAH, which can interfere with the treatment of the individual himself or his family members affected by the disease. However, when checking the comparison between the two groups (people with or without SAH) it was found that those with SAH know more about the disease.

Participants with SAH obtained higher scores, both on the general scale and in four subdimensions. The only subdimension with a higher average score in the group of people without SAH was "medication adherence". "Medical treatment" was the only subdimension that showed no significant difference.

Corroborating this result, a study that used HK-LS to assess the knowledge of Jordanian adults, with and without $\mathrm{SAH}$, also found a significant difference between the two groups, in which the group with hypertension obtained higher scores of knowledge on the entire instrument and in all evaluated subdimensions ${ }^{(13)}$.

As for the reliability of the Brazilian version of HK-LS, the result obtained demonstrated that it is reliable in measuring knowledge about arterial hypertension. Still, it is possible to emphasize that the reliability of the scale is in accordance with the data obtained in another study in which this scale was applied ${ }^{(14)}$.

Cronbach's alpha coefficient for each subdimension demonstrated that the lowest values refer to "medical treatment" and "definition". As already mentioned, during data collection, it was observerd difficulty in understanding the statements that make up the "definition" subdimension".
With regard to "medical treatment", some participants, in their speeches, demonstrated to know the correct option, but mentioned, as an official answer, the option that reflected their reality. For example, for the statement "Medication for high blood pressure should be taken daily", many said they should, but did not take them daily. As the researchers could not interfere in the answer, even identifying the adequate knowledge about the affirmative, what the participant considered as the official answer prevailed.

In addition, during data collection, it is also possible to perceive contradictory responses in opposite statements. For example, the statement"Medicines for high blood pressure should be taken daily" differs from the statement "People with high blood pressure should take their medicines only when they feel bad". However, some participants declared both to be correct. Thus, the variability of responses in the "medical treatment" subdimension, which refer to the habits of taking antihypertensive medication, may justify the low value of Cronbach's alpha coefficient.

The statistical analysis also demonstrated that the removal of statements from the "medical treatment" subdimension or the removal of the subdimension as a whole would not increase the value of Cronbach's alpha. Therefore, it is inferred that, although the alpha of this subdimension had a value below the expected, the variables that compose it have a correlation with the rest of the scale and there is no need to remove items.

The analysis of variance indicated that the Brazilian version of the HK-LS has a $p<0.01$, that is, there is statistical significance between the variability of the responses of the research participants, so that no item in the Brazilian version of the HK-LS can be discarded.

As for Pearson's Linear Correlation, it was observed that among the 22 items of the Brazilian version of HK-LS, items 14 and 15 , referring to the "diet" subdimension, presented a higher correlation than the others, in the value of 0.540 . For the other items, the low correlation shows that these can be considered as independent questions, although on the same subject. When taking into account the instrument's subdimensions, it is noticed that all negative correlations occur in items of different subdimensions, with the exception of the correlation of items 11 and 17 that are part of the "lifestyle" subdimension.

For example, the correlation between items 1 and 12 is -0.100 , that is, they are not correlated with each other, however, when observing the content of each item, it is noticed that these are part of different subdimensions of the instrument ("definition" and "medication adherence", respectively), showing the logic of the instrument as a 
whole evaluating knowledge, however, being divided into different subdimensions.

It was observed that the correlation between the items remained low, which leads to the understanding that the instrument is logical in its construction and demonstrates independence between the items, a fact that corroborates with the statement that, when these values remain low, the concepts of each item can be interconnected in the formation of the instrument, measuring different faces of the same construct ${ }^{(15)}$.

It is noteworthy, however, that external factors may interfere in the assessment of the "knowledge" construct, such as the level of education of the participants and, in the case of the Brazilian version of HK-LS, the technical terms used in the questions. This difficulty was mentioned in another study ${ }^{(16)}$, which suggested a positive correlation between education and knowledge, when using HK-LS in Iran.

The use of knowledge instruments can be a strategy for planning care, allowing the professional to provide precise guidance to the patient, according to their need and ability of understanding.

Knowledge assessment can even be a factor to be considered in the risk stratification of hypertensive patients, as it was found that this variable interferes with therapeutic adherence and, consequently, with cardiovascular outcomes, providing the individual and their family members the necessary knowledge to control the disease, in order to increase the quality and life expectancy of the hypertensive patient while reducing the risk of complications ${ }^{(17)}$.

It is understood that it is up to the nurse professional, through the identification of the level of knowledge of his patients about SAH, to carry out health education actions that contribute to add knowledge about SAH and develop strategies so that patients with SAH understand her illness and know the best way to live with it in a healthy way.

It is worth mentioning that the validation of the psychometric properties of an instrument is strongly recommended, thus, the results of this research complement those presented in previous research ${ }^{(5)}$, showing that in addition to the content of the scale being valid, it is also reliable and has construct validity, affirming its use by the health team in measuring knowledge, raising a situational diagnosis and consequently developing strategies for care.

\section{CONCLUSION}

The Brazilian version of HK-LS demonstrated to have a valid construct and is reliable for measuring knowledge about $\mathrm{SAH}$, as well as the criterion measured by discriminant validity, as its scores were specifically more affected for the group of people with SAH.

It is reinforced the indication of the scale to assess the level of knowledge about SAH as an instrument for the performance of health professionals in primary care, since these scores contribute to case management. By helping health professionals to direct educational actions and care planning, the patient's empowerment for care is promoted and, consequently, the reduction in the likelihood of developing associated complications.

The difficulty in understanding of some participants was considered a limitation of this study, as the low level of education found and the respective capacity for interpretation may interfere with the application of the instrument.

\section{Q REFERENCES}

1. Almeida JS, Almeida JM. A educação em saúde e o tratamento do diabetes mellitus tipo 2 em uma unidade de saúde da família. Rev Fac Ciênc Méd Sorocaba. 2018 [citado 2019 set 10];20(1):13-7. doi: https://doi. org/10.23925/1984-4840.2018v20i1a4

2. Motta MDC, Peternella FMN, Santos AL, Teston EF, Marcon SS. Educação em saúde junto a idosos com hipertensão e diabetes: estudo descritivo. Uningá Rev. 2018 [citado 2019 out 10];18(2):48-53. Disponível em: http://revista.uninga. br/index.php/uningareviews/article/view/1502

3. Ministério da Saúde (BR). Secretaria de Atenção à Saúde. Departamento de Atenção Básica. Estratégias para o cuidado da pessoa com doença crônica: hipertensão arterial sistêmica. Brasília (DF): Ministério da Saúde; 2013 [citado 2019 out 3]. Disponível em: http://bvsms.saude.gov.br/bvs/publicacoes/ estrategias_cuidado_pessoa_doenca_cronica.pdf

4. Ercok SB, Isikli B, Metintas S, Kalyoncu C. Hypertension Knowledge-Level Scale (HK-LS): a study on development, validity and reliability. Int J Environ Res Public Health. 2012;9:1018-29. doi: https://doi.org/10.3390/ijerph9031018

5. Arthur JP, Mantovani MF, Ferraz MIR, Mattei AT, Kalinke LP, Corpolato RC. Translation and cross-cultural adaptation of the Hypertension KnowledgeLevel Scale for use in Brazil. Rev Latino-Am Enfermagem. 2018;26:e3073. doi: https://doi.org/10.1590/1518-8345.2832.3073

6. Hair JF, Black WC, Babin BJ, Anderson RE, Tatham RL. Análise multivariada de dados. 6a ed. Porto Alegre: Bookman; 2009.

7. Souza AC, Alexandre NMC, Guirardello EB. Psychometric properties in instruments evaluation of reliability and validity. Epidemiol Serv Saúde. 2017;26(3):649-59. doi: https://doi.org/10.5123/s1679-49742017000300022

8. Ferreira RC, Padilha BM, Pedrosa YESS, Ferreira RB, Cabral PC, Vasconcelos SML. Perfil clínico-epidemiológico dos portadores de hipertensão atendidos na atenção básica do estado de Alagoas. Medicina (Ribeirão Preto) 2017;50(6):34957. doi: https://doi.org/10.11606/issn.2176-7262.v50i6p349-357

9. Medeiros Filho RA, Maciel APF, Pimenta HB, Caldeira AP. Prevalence of behaviors and risk factors for cardiovascular diseases in hypertensive population in the north of Minas Gerais, Brazil. Rev Pesqui Fund Care Online. 2018;10(1):90-6. doi: https://doi.org/10.9789/2175-5361.2018.v10i1.90-96 
10. Gomes IV, Sousa LS, Meneses ASS, Mendes JMS, Queiroz XSBA, Almeida TCF. Caracterização dos usuários hipertensos atendidos em unidade de pronto atendimento 24 horas. Rev Nurs, 2018 [cited 2019 Sep 10];21(239):21148. Disponível em: http://revistanursing.com.br/revistas/239-Abril2018/ caracterizacao_dos_usuarios_hipertensos_atendidos.pdf

11. Malachias MVB, Souza WKSB, Plavnik FL, Rodrigues CIS, Brandão AA, Neves MFT, et al. 7th Brazilian Guideline of Arterial Hypertension. Arq Bras Cardiol. 2016 [cited 2019 Sep 3];107(3 Suppl. 3):1-83. Available from: https://www. scielo.br/pdf/abc/v107n3s3/0066-782X-abc-107-03-s3-0000.pdf

12. Kroth KB, Silva CD, Kroth JB, Maia HMSF. Factors associated with uncontrolled arterial hypertension in patients from primary health care. J Physiother Res. 2017;7(4):538-47. doi: https://doi.org/10.17267/2238-2704rpf.v7i4.1636

13. Eshah NF, Al-Daken LI. Assessing public's knowledge about hypertension in a community-dwelling sample. J Cardiovasc Nurs. 2016;31(2):158-65. doi: https://doi.org/10.1097/JCN.0000000000000227

14. Chatziefstratiou AA, Giakoumidakis K, Fotos NV, Baltopoulos G, BrokalakiPananoudaki $H$. Translation and validation of the Greek version of the hypertension knowledge-level scale. J Clin Nurs. 2015;24(23-24):3417-24. doi: https://doi.org/10.1111/jocn.12906
15. Sousa CF, Santos C, Graça LCC. Construção e validação de uma escala de adaptação a ostomia de eliminação. Rev Enf Ref. 2015;serlV(4):21-30. doi: https://doi.org/10.12707/RIV14021

16. Motlagh SFZ, Chaman R, Ghafari SR, Parisay Z, Golabi MR, Eslami AA, et al. Knowledge, treatment, control, and risk factors for hypertension among adults in Southern Iran. Int J Hypertens. 2015;2015:897070. doi: https://doi. org/10.1155/2015/897070

17. Leal LB, Leal NTB, Sousa EC, Pereira KLA, Negreiros ALB, Silva ARV. Educational intervention performed with hypertensive of a Family Health Strategy. Rev Enferm UFPI. 2016;5(3):67-71. doi: https://doi.org/10.26694/reufpi.v5i3.5082

\section{Acknowledgment:}

We are grateful to the National Council for Scientific and Technological Development (Conselho Nacional de Desenvolvimento Científico e Tecnológico CNPq) for the grant of the Research Productivity Scholarship and for the grant of Scientific Initiation scholarships that made this study possible.

\section{- Corresponding author:}

Mireille Janczyk Hereibi

Email: mireille.jh@gmail.com

\section{Associate editor:}

